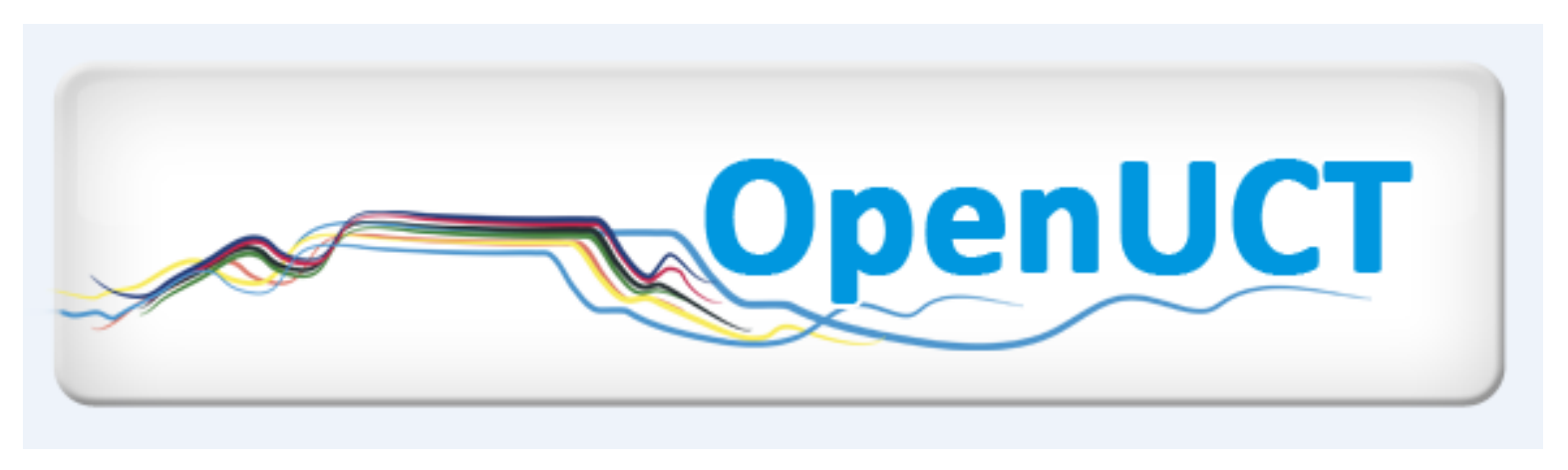

This is the post-print of Hodgkinson-Williams, C. \& Paskevicius, M. 2012. The role of postgraduate students in co-authoring open educational resources to promote social inclusion: a case study at the University of Cape Town. Distance Education. 33(2): 253-269. DOI:

10.1080/01587919.2012.692052.

It is made available according to the terms of agreement between the author and the journal, and in accordance with UCT's open access policy available:

http://www.openuct.uct.ac.za/sites/default/files/UCTOpenAccessPolicy.pdf, for the purposes of research, teaching and private study. 


\title{
The role of postgraduate students in co-authoring open educational resources to promote social inclusion: a case study at the University of Cape Town
}

\author{
Cheryl Hodgkinson-Williams and Michael Paskevicius \\ Centre for Educational Technology, University of Cape Town, Cape Town, South Africa
}

\begin{abstract}
Like many universities worldwide, the University of Cape Town (UCT) in South Africa has joined the open educational resources (OER) movement, making a selection of teaching and learning materials available through its OER directory, UCT OpenContent. However, persuading and then supporting busy academics to share their teaching materials as OER still remains a challenge. In this article, we report on an empirical study of how UCT postgraduate students have assisted in the process of reworking the academics' teaching materials as OER. Using the concept of contradictions (Engeström, 2001), we endeavor to surface the various disturbances or conflicts with which the postgraduate students had to engage to make OER socially inclusive, as well as Engeström's "layers of causality" (2011, p. 609) to explain postgraduate students' growing sense of agency as they experienced the OER development process as being socially inclusive.
\end{abstract}

Keywords: open educational resources; social inclusion; activity theory; contradictions; agency

\section{Introduction}

The University of Cape Town (UCT) committed itself to the open educational resources (OER) movement by signing the Cape Town Open Education Declaration in April 2008 (Shuttleworth Foundation, n.d.). In February 2010, UCT launched its OER directory, UCT OpenContent, formalizing a process of informal and ad hoc sharing of teaching materials that was already common practice in a few departments or by individual lecturers (Hodgkinson-Williams \& Donnelly, 2010). Opening up some of UCT's teaching and learning materials is one way in which UCT is enacting its vision to be an "Afropolitan university" by "promoting an inclusive institutional climate in which South African students and students from the rest of the continent, engage with histories, bodies of knowledge and thought leaders from their own heritage" (UCT, 2009, p. 7). African universities have found it "extremely challenging and complex to find their footing on the global higher education stage - they barely register on world institutional rankings and league tables and produce a tiny percentage of the world's research output" (Altbach, Reisberg, \& Rumbley, 2009, p. v). Besides which there are few learning materials for students and lecturers in African 
universities, and many that are available are very expensive (Ngugi, 2011).

The rhetoric of OER fostering social inclusion is compelling as OER enthusiasts suggest that access to educational resources can play a role in "reducing social inequalities, fostering social inclusion of migrants, and supporting education in developing countries" (Geser, 2007, p. 57), as well as being an efficient way of promoting lifelong learning and bridging the "gap between informal and formal learning" (Ehlers, 2011, p. 8). There have been a number of specific suggestions made that OER can promote social inclusion through "easy access to resources that may otherwise not be accessible by potential user groups" (Geser, 2007, p. 21); through widening participation to a range of OER in various disciplines (Coughlan \& Perryman, 2011); by designing and presenting OER in ways that are "suited to the learners as much as the educators and the institution" (Lane \& van Dorp, 2011, p. 1363), and by "establishing OEP [open educational practices] to promote openness of learning architectures and transforming learning scenarios" (Ehlers, 2011, p. 8).

The concept of social inclusion is a "contested term in both the academic and policy literature with a diversity of definitions available" (Gidley, Hampson, Wheeler, \& Bereded-Samuel, 2010, p. 128). It is often used in relation to OER without a specific definition (Geser, 2007) or in association with other concepts such as social exclusion (Conole, 2011), widening participation (dos Santos, 2008), and social justice (Gourley \& Lane, 2009). It would seem from the current OER discourse that gradations of social inclusion exist, extending from mere access to knowledge, to teaching and learning materials, through to transformative practices in knowledge creation. But as dos Santos (2008) highlighted, "in the OER movement, knowledge also means power" (p. 7), which means that there are probably gradations of power sharing in the OER process that extend from minimal power sharing by the granting of access to existing teaching and learning materials by academics to the general public to extensive power sharing in collaborative OER development among academics, students, and self-learners to a complete power shift in user-generated content.

Around the world there are a number of OER implementation and research projects, some of which focus specifically on user-generated content, such as LabSpace (Gourley \& Lane, 2009), the CONCEDE project (Wheeler, 2010), and the OpenScout project (Little, Mikroyannidis, Okada, \& Scott, 2011). Empirical studies of OER development or adaptation highlight the role of academics in making their teaching and learning materials available as OER (Littlejohn, Jung, \& Broumley, 2003; Philip \& Cameron, 2008); the role of teachers in collaborative OER development (Sapire \& Reed, 2011); the role of teacher educators and policymakers (Wolfenden, 2008); the role of student volunteers (Paskevicius, 2011); and the role of students in creating their own content (Lee \& McLoughlin, 2007), but seldom focus on the role of students in assisting academics (cf., Canby, Hutchful, Kleymeer, \& Ngo, 2007, and Kleymeer, Kleinman, \& Hanss, 2010, for discussions on the use of postgraduate students at the University of Michigan). Although some OER guidelines suggest that "student bodies can actively support and promote strategies to allow students to assist in sourcing, adapting and producing OER in partnership with academic staff' (Commonwealth of Learning, 2011, p. 12), there seems to be limited empirical research on how postgraduate students or interns adapt academics' teaching and learning materials and how this can contribute to supporting the creation of OER. 


\section{Theoretical perspectives in OER research}

Not all OER research specifically adopts explicit theoretical perspectives, but some studies have drawn upon communities of practice in supporting reuse within communities of educators (Harris \& Higgison, 2003); genre theory to analyze the reusability of learning objects (Honkaranta \& Tyrväinen, 2005); activity theory as a lens to investigate how the various aspects in the adaptation of OER influence an entire system (McAndrew, 2006); or an element of activity theory such as "mediating artefacts" (Conole, McAndrew, \& Dimitriadis, 2010) to understand the repurposing of existing OER.

Following McAndrew (2006) and Conole et al. (2010), this article adopts the conceptual framework of activity theory, specifically the concepts of contradictions (Engeström, 2001) and layers of causality (Engeström, 2011) to surface the role that postgraduate students play in assisting academics to adapt existing materials as OER and how this might support social inclusion. Conole et al. (2010) posited learning materials to be the mediating artifacts, or tools, which are created as a result of, or used within, activity systems. They asked how tools designed in the context of one activity system can be appropriately repurposed within new systems of activity and new contexts. The particular research question that this article seeks to address is: What is the role of postgraduate students in co-authoring OER and how might this promote social inclusion?

\section{Activity theory and contradictions to surface key issues in the OER co-authoring process}

As the practice of OER authoring and adaptation involves a range of people (usually academics, instructional designers, and/or students) developing materials according to specific rules (e.g., alternative intellectual property systems, interoperability standards, metadata systems) using specific tools (e.g., learning management systems [LMSs], repositories, Web 2.0 tools), for a broader community with multiple points of view, Engeström's third generation of activity theory provides a useful way of describing the interplay between these elements and surfaces some of the disruptions and/or transformations occurring within the OER development process (2001).

\footnotetext{
An activity system is always a community of multiple points of view, traditions and interests. The division of labor in an activity creates different positions for the participants, the participants carry their own diverse histories, and the activity system itself carries multiple layers and strands of history engraved in its artifacts, rules and conventions. The multi-voicedness is multiplied in networks of interacting activity systems.

It is a source of trouble and a source of innovation, demanding actions of translation and negotiation. (Engeström, 2001, p. 136)
}

The activity system model takes into account the broader social context experienced by individuals acting collectively, as individuals are subject to rules, interact with the community, and take on certain roles when engaging in any kind of social activity; in this case adapting existing teaching and learning materials to be shared as OER.

To understand the possible disruptions and/or transformative potential of postgraduate students in assisting academics in co-authoring OER to promote social 
inclusion, Engeström's concept of contradictions (2001) is a useful theoretical lens to surface the various disturbances or conflicts with which the postgraduate students had to engage to make OER socially inclusive. Engeström emphasized the central role of contradictions in an activity system by explaining that "contradictions [are] sources of change and development ... [and] are not the same as problems or conflicts ... [but are rather] historically accumulating structural tensions within and between activity systems" (2001, p. 137). This concept of contradictions is particularly useful in understanding the new structural tensions the OER movement has introduced through bringing a new activity into higher education. As Engeström explained:

\begin{abstract}
When an activity system adopts a new element from the outside (for example, a new technology or a new object), it often leads to an aggravated secondary contradiction where some old element (for example, the rules or the division of labor) collides with the new one. Such contradictions generate disturbances and conflicts, but also innovative attempts to change the activity. (p. 137)
\end{abstract}

In other words, if we can identify the disturbances and conflicts, but also innovative attempts to change around curricula and pedagogic practice introduced by OER, we are likely to be able to identify potentially helpful options to overcome these obstacles and support innovation, which in this case is ensuring the materials are as socially inclusive as possible.

\title{
Agency as a layer of causality to surface key issues in the OER co-authoring process
}

In a more recent article, Engeström (2011) introduced the notion of "agency as a layer of causality" within activity systems. Causality is understood to be an observable process that can explain decisions made during a series of events (Engeström, 2011). Engeström discussed agency in terms of causality, which may be organized in three layers. At the interpretive layer individuals use logic, laws, and rules to form their interpretations of activities. At the contradictory layer subjects encounter disruptions or contradictions "between multiple motives embedded in and engendered by their historically evolving communities and objects" within activity systems, which may result in subjects appearing to be acting "irrational[ly] or unpredictabl[y]" (Engeström, 2011, p. 610). Finally, the agentive layer of causality allows individuals to transform or innovate in situations using new tools available under new conditions of rules, community, or division of labor. Engeström went on to explain that deviating from a pre-existing pattern of activity requires expansive agency and can be broken down using these three levels of causality (Figure 1).

Furthermore, a central principle of Engeström's third generation of activity theory is the concept of expansive transformations in activity systems (2001). These are "accomplished when the object and motive of the activity are reconceptualised to embrace a radically wider horizon of possibilities than in the previous mode of the activity" (p. 137). This concept is helpful in describing the processes involved in reconceptualizing OER for a broader audience. Engeström maintained that "a collective activity is driven by a deeply communal motive" (2000, p. 964). In this case, the motive is sharing a selection of teaching and learning materials so that they are as socially inclusive as possible. 


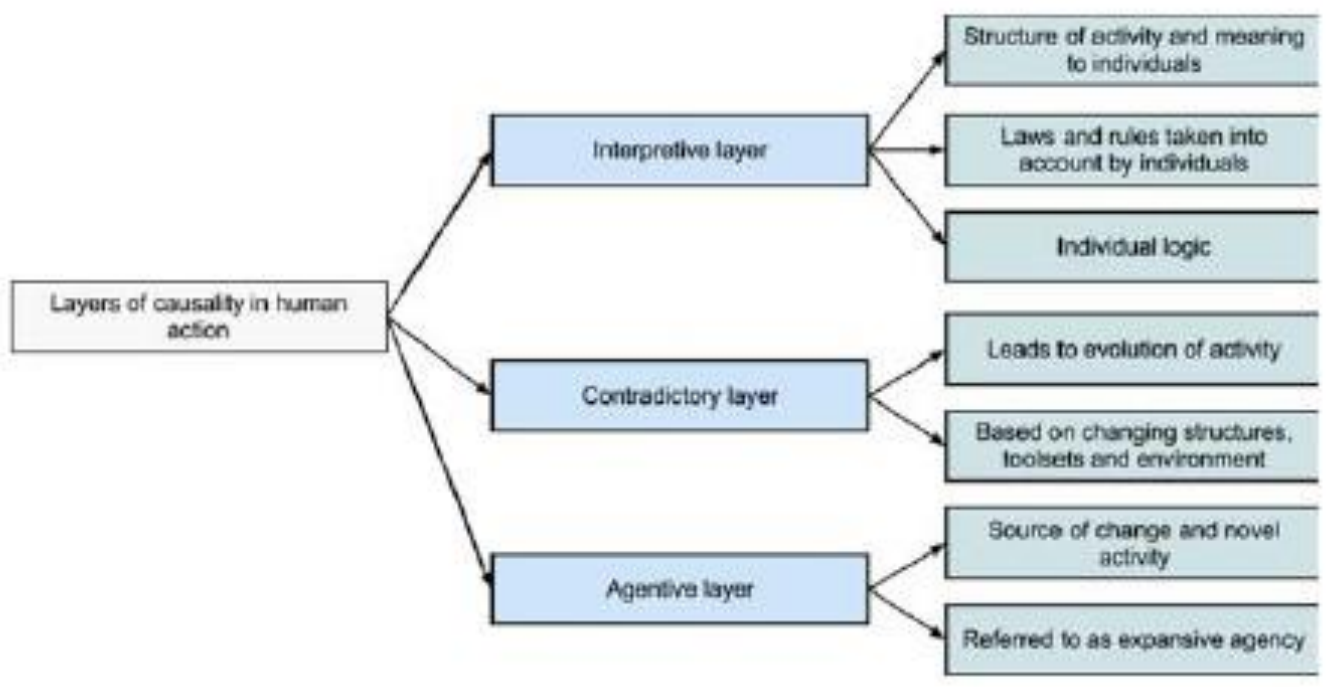

Figure 1. Engeström's three layers of causality (adapted from Engeström, 2011, p. 610).

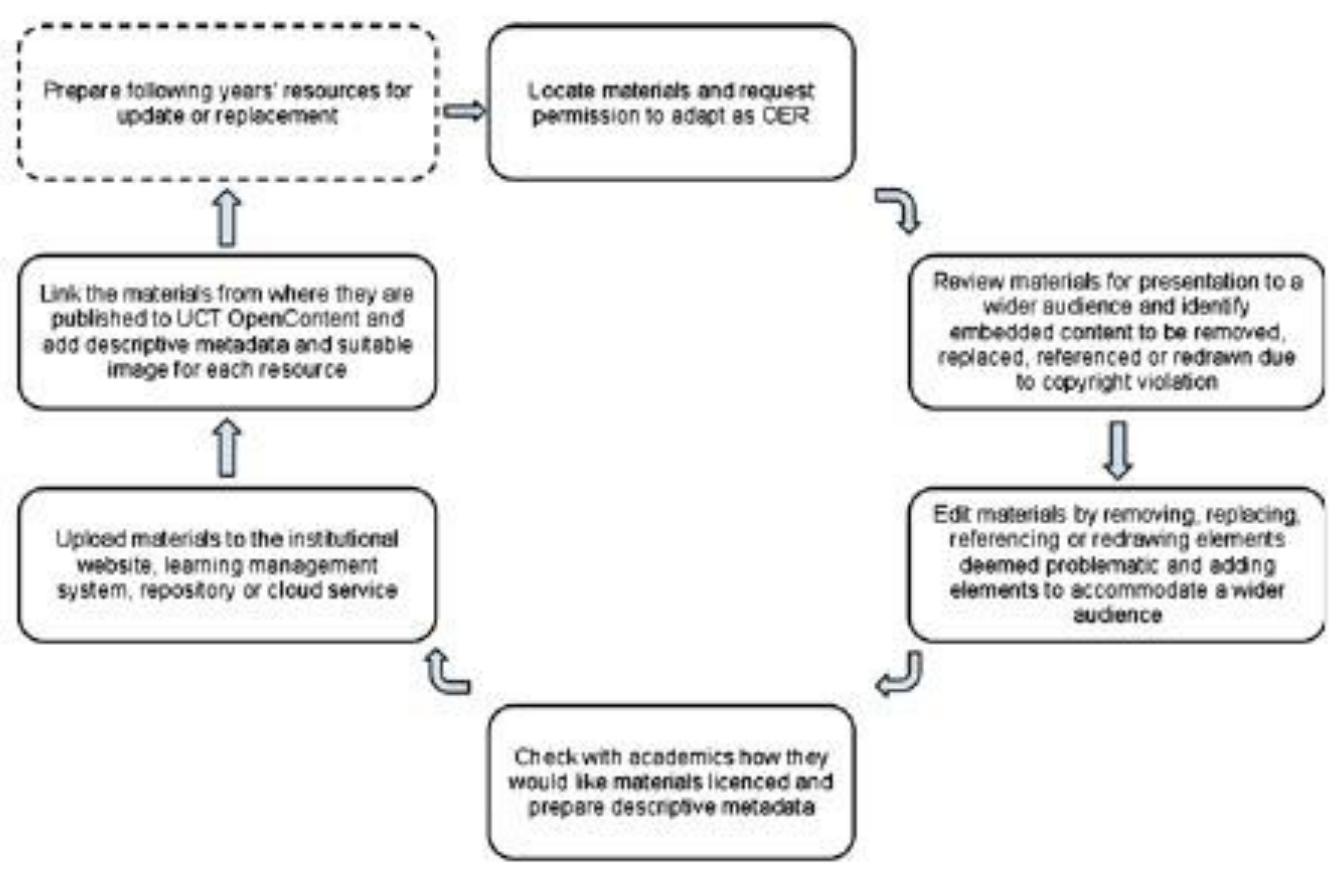

Figure 2. The UCT OER adaptation process adapted from the dScribe process (University of Michigan, 2011).

\section{OER co-authoring process at UCT}

In planning how to use postgraduate students to support academics to rework a selection of existing teaching materials as OER, the OER team in the Centre for Educational Technology (CET) and in the Health Science Faculty at UCT drew heavily on the University of Michigan's dScribe process (2011). Contact was made directly with OER staff at the University of Michigan and information exchanged through face-to-face visits, follow-up emails, and regular Skype calls, as very little information has been formally published, apart from the comprehensive dScribe Open.Michigan wiki. The OER team adapted the dScribe process for UCT's context (Figure 2). 
The OER process includes postgraduate students being centrally involved in locating materials and requesting permission to adapt them. They were also involved in reviewing materials for presentation to a wider audience and identifying embedded content to be removed, replaced, referenced, or redrawn due to copyright violation; editing materials by removing, replacing, referencing, or redrawing elements deemed problematic, and adding elements to accommodate a wider audience; checking with academics on how they would like materials licensed and preparing descriptive metadata; uploading materials to the institutional Web site, LMS, repository or cloud service; and linking the materials from where they are published to UCT OpenContent and adding descriptive metadata and suitable images for each resource.

\section{Case study of using postgraduate students to assist academics}

This small case study attempts to interrogate the "particularity and complexity" (Stake, 1995, p. xi) of OER adaptation by postgraduate students at UCT (Table 1) as a pilot for a more extensive study. To provide an overview of the different types of engagement with academics, two groups of students were interviewed. The first group of three students were appointed by their lecturer, who had been awarded a small grant to adapt teaching and learning materials already available on the department's Web site. This material was not appropriately licensed or free of embedded copyrighted materials. The second group of three students were employed in either one of two OER projects at UCT: OER UCT Project (http://www.cet.uct.ac.za/oer) funded by the Shuttleworth Foundation and the inter-institutional project African Health OER Project (http://www.oerafrica.org/healthoer/) funded by the Hewlett Foundation. All six were either master's students or had recently completed their master's degrees.

Semistructured interview questions were devised to elicit responses from the six students and were emailed to them prior to the interview. One student completed the emailed questions instead of being interviewed and another student decided to respond to the questions in the email and to participate in the interview as well. Questions for clarification were sent via follow-up emails to the students and then

Table 1. Postgraduate student demographic details.

\begin{tabular}{|c|c|c|c|c|c|}
\hline \multicolumn{2}{|c|}{ Student Qualifications } & Year & $\begin{array}{l}\text { Appointment } \\
\text { by }\end{array}$ & $\begin{array}{l}\text { Years } \\
\text { supporting } \\
\text { OER }\end{array}$ & Nationality \\
\hline 1 & MSc_current & 2nd & Department & 1.5 & $\begin{array}{l}\text { South } \\
\text { African }\end{array}$ \\
\hline 2 & MSc_current & $3 r d$ & Department & 5 & $\begin{array}{l}\text { South } \\
\text { African }\end{array}$ \\
\hline 3 & MSc-completed & - & Department & 4.5 & Zimbabwean \\
\hline 4 & $\begin{array}{l}\text { Master of Laws (LLM)- } \\
\text { completed }\end{array}$ & - & $\begin{array}{l}\text { UCT OER } \\
\text { Project }\end{array}$ & 2 & $\begin{array}{l}\text { South } \\
\text { African }\end{array}$ \\
\hline 5 & $\begin{array}{l}\text { MSc Environmental \& } \\
\text { Geographical Science-current }\end{array}$ & $1 \mathrm{st}$ & $\begin{array}{l}\text { Health OER } \\
\text { Project }\end{array}$ & 1.5 & $\begin{array}{l}\text { South } \\
\text { African }\end{array}$ \\
\hline 6 & $\begin{array}{l}\text { MPhil ICT in Education- } \\
\text { current }\end{array}$ & $3 r d$ & $\begin{array}{l}\text { UCT OER } \\
\text { Project }\end{array}$ & 3 & Canadian \\
\hline
\end{tabular}


each hour-long interview was transcribed and sent back to the respondents for member-checking (Maxwell, 2008).

A process of thematic coding (LeCompte, 2000) was applied to identify the emergent ideas and categorize them in relation to the activity theory framework. Obviously, the very small number of participants limits the generalizability of the study, but it does help to identify the kinds of activities that postgraduate students will need to undertake in reworking OER and how their engagement might be explained theoretically.

\section{Findings}

To understand how postgraduate students assisted academics to make a selection of their teaching materials available as OER to increase access to knowledge to others, their activities are analyzed according to the key contradictions in the activity system (Engeström, 2001) and are discussed first before turning attention to how this process reflected the students' growing sense of agency.

\section{Expanding the object-envisaging a public audience}

One way in which postgraduate students were able to assist academics in making OER socially inclusive was to reinterpret the materials to be suitable for a public audience thereby "expand[ing] the object" (Engeström, 2001, p. 149). In the process of adapting materials as OER, postgraduate students reconceptualized the object of the activity by taking into account a wider audience's needs and imagining what a non-UCT student might need to know to make sense of the OER. As most of the postgraduate students emanated from Africa or had worked and studied in Africa for at least 6 years, they were in a position to imagine the kinds of issues they would need to consider to optimize OER use by non-UCT students in general and by African students and/or lecturers in particular.

The commitment to share with African learners was a constant thread through the interviews with the students, either in general or more specifically, as the following quotations reveal:

I guess often as Africa wants to learn from Africa, it is something that we should be striving for and to create resources that are [readily] available. (Student 5)

People who would not necessarily even have qualified to attend universities are now starting to learn about university type subjects, so that's a big benefit.... Obviously some African universities do not have the expertise that UCT happens to have or Stellenbosch [university]. (Student 4)

One Zimbabwean student provided a specific example of how OER could be beneficial to his country in particular:

I have been involved in an initiative organized by the Council for Assisting Refugee Academics (CARA) and the International Organisation of Migration (IOM) to find ways of addressing the brain drain it is experiencing. One of the key ways that this initiative identified as a high-impact, cost-effective way of doing this is to make use of filmed or streamed lectures in advanced topics delivered by experts outside Zimbabwe. (Student 2, email) 
Given that they understand the African context quite well, the postgraduate students were quite skilled at noting the issues that needed to be addressed, which included the need for removing context-specific information so that the resource is more useful to a wider audience:

In some cases we even consider preparing the resource for a more generalized audience, so that the UCT specific content is taken out. (Student 6)

One student noted the need to include additional information to make the materials more comprehensible without the verbal commentary that would usually have accompanied the PowerPoint presentations:

So I am a lot more explicit in the things that I do, and I often have hidden slides in which I "chalk and talk" that part of what I do in class. But in the slides I will have what I've "chalked and talked" for completeness. (Student 2)

The same student went on to explain how they removed slides to make the message clearer and to ensure that each element was necessary:

Many times in the slides, especially the slides that we didn't include, people felt that they had to fill every available bit of space. There was some extraneous stuff and in many cases it was really innocuous like here's a picture of Newton or whatever. Sometimes they would have a diagram just for its own sake, and afterwards you would think, how does this actually relate? (Student 2)

Where possible, to increase the potential for social inclusion, OER shared at UCT were made available in a language other than or in addition to English:

Many of the resources we actually created contained multilingual content. As South Africa has 11 official languages and many students struggle to perform at university using English as second language, I think having the materials in as many languages as possible is really valuable. One of the resources, a Guide for First Year Students, has some text in Afrikaans and Xhosa and I hear it is being used at a number of other South African universities. (Student 6)

Student 2 also illustrated that the reconceptualization of materials as OER needs to make explicit how individual materials link together and how one would progress from one to the next:

We added that because now people are looking, and they want to show that there is a progression and a structure there. Also they were keen to not only have the slides, but also to have problem sets and tutorials and so on. (Student 2)

By reinterpreting the materials and thereby expanding the object, the postgraduate students were transforming the original materials prepared by the academics. However, herein lies a tension between practices, as one student insightfully commented:

In the end I noticed that many OERs that we share look quite different than the original teaching resource. I often wonder if the academic continues using the old resource and the OER is just a snapshot of the material. What I would prefer is that 
the academic uses the new content and continues developing it with open practices. (Student 6)

What becomes clear is that unless the academics are committed to ongoing OER development, the danger is that the OER version of the materials created to optimize social inclusion is not reused within the original context or newer versions of the original materials are not included in the OER. In other words, there is a need for a "shared or jointly constructed object" (Engeström, 2001, p. 136) between the academics and the postgraduate students to optimize OER adaptation by negotiating responsibilities.

\title{
Expanding the division of labor-negotiating responsibilities
}

Another way in which the postgraduate students were able to assist academics in making OER socially inclusive was by taking on a number of activities that academics would otherwise not have time to do or perhaps not have the competence or interest. For example, the postgraduate students are quite familiar with the range of OER hosting platforms, other than the institutional Sakai-based LMS called Vula (which means open in a number of indigenous languages in Africa). One student noted the challenge of trying to persuade academics to upload materials to a cloud-based service for hosting presentations and photographs:

\begin{abstract}
I think the minute you suggest something else other than Vula to an academic you kinda lose them. The minute you say, you can put it up on SlideShare, they say you put it up on SlideShare, you have to put it on an account ... You can put it on Flickr, it's always, you put it on Flickr. Now you have to create an account and then upload it and that's normally where you lose people. (Student 4)
\end{abstract}

As many UCT academics make use of Vula, they are not necessarily familiar with using cloud-based services or the UCT OpenContent directory for sharing materials. Although the uploading process in the UCT OpenContent directory has been made as user-friendly as possible so that academics have control over uploading or taking down their own resources, the postgraduate students pointed out that this still requires extra effort from the academics and that they often take on this role:

It is much easier for lecturers to put their slides up on the [departmental] Web site than to have it shared (and verified) through UCT OpenContent. It requires more effort on the part of the lecturers to ensure that materials are shared legally, and it makes updating slides more difficult. On the other hand, access to UCT OpenContent will be encouraged and advertised, so the advantage of sharing via UCT OpenContent would be that the audience reached would be far broader. (Student 3, email)

Postgraduate students are therefore taking on additional responsibilities, not only to save the academics' time, but also because the academics may not have the competence to or value the need for sharing OER on platforms that make public access to the materials possible.

This is therefore a good example of what Engeström (2001) referred to as an "aggravated secondary contradiction" (p. 137), where the current practice of uploading materials to the LMS collides with the new practice of taking advantage of the affordances of hosting material on a range of platforms and linking such 
material to a central directory. As Engeström pointed out, although "such contradictions generate disturbances and conflicts, [they also generate] innovative attempts to change the activity" (p. 137). There is therefore an opportunity for academics if they can be persuaded to see the potential value of sharing not only teaching materials, but also research materials, as suggested by Student 6:

For academics I believe that sharing materials on the Web represents a new form of scholarly activity which academics should be engaging in. The Internet facilitates the sharing of ideas and research which may allow for the quicker dissemination of knowledge and increase possibilities for global collaboration. (Student 6)

\title{
Expanding the too- using a range of appropriate tools
}

Yet another way in which the postgraduate students were able to assist academics in making OER socially inclusive was to ensure that the tools used, both external (e.g., Web-based tools) or internal (e.g., media formats), suited the needs of the potential users of the OER. The postgraduate students were aware of the value of certain media in mediating difficult concepts:

\begin{abstract}
These are videos which show how to do [run physics demonstrations], how you can analyze it and what you can get out of it. I think that is very useful, as our labs are generally quite well run. These would be really useful to others, especially in Africa. My impression is that theory is generally done well because it's cheap, but labs are not because you need resources. We have a YouTube channel where some of the videos are starting to be hosted. (Student 2)
\end{abstract}

However, the postgraduate students were aware of the constraints of various media for those, especially in Africa, who have relatively low bandwidth and lack the necessary equipment:

But once you start sharing videos you have to consider the bandwidth costs. When sharing lectures slides it's just nothing really, but when sharing videos it's a huge chunk of bandwidth. (Student 3)

They were also aware that the format of the materials needed to be suitable to the potential user's needs as some formats are more difficult to edit or require specific software to use. The postgraduate students were also cognizant of the need to conceptually link various resources together in order to mediate the OER to other users.

While many resources were available in PDF, PPT, or Word files we often had to add a page to describe a set of resources which could be accessed. This was usually in the form of an HTML course page or something along those lines which could contextualize the resources in the collection. (Student 6)

Overall, it would seem that the postgraduate students had a better sense of the appropriate tools than the academics:

Working with a variety of departments has been a challenge. Different departments have different capabilities and facilities which we can draw on for sharing OER.... Using students in the process was helpful as many had pretty solid understanding of how to share things on the web, which was a key skill for helping get academics' materials online. (Student 6) 
So once again an "aggravated secondary contradiction" (Engeström, 2001, p. 137) seems to be present as the academics' competence in using appropriate Web-based tools or willingness to share more widely was in conflict with their usual practice of uploading PowerPoint slides to Vula for use by UCT students only. But as Engeström (2011) noted, the contradictions generate "innovative attempts to change the activity" (p. 609), which is exactly what the postgraduate students did by identifying and using the most appropriate tools to make OER more accessible.

\title{
Expanding the rules-adopting new rules
}

Another critical area in which the postgraduate students supported the academics was in selecting the appropriate Creative Commons license for the OER. Student 6 noted that "Copyright naturally was the big one for most academics," suggesting that the new intellectual property rules were an area with which academics had little familiarly and that "moving to sharing resources online definitely created some new considerations for people traditionally just sharing resources with the classroom" (Student 6).

Although students generally negotiated the clearing of embedded copyright quite easily, there were times when they were confronted with extensive infringement of copyright.

\footnotetext{
Normally they are fine, I mean there have been instances, with [department] where they actually told me, well they know copyright law, and they know that that image is not problematic at all. I mean you do get your one odd or two, but generally the response has been quite ok, either yes we'll find alternatives for it or we don't have time to. (Student 4)
}

\begin{abstract}
Well some of the older academics, especially in the days when it was transparencies rather than slides, they would just photocopy bits out of books and project it on the screen, and it could be a whole chapter you know! And often there was not editing at all from these chaps. (Student 2)
\end{abstract}

Although the students maintained that "OER creates less infringement of copyright" (Student 5), they suggested that the academics "just don't see it as part of their jobs and for others it just too much effort and for others they probably just don't know that there is the option of open licensing" (Student 4).

Once again, the contradiction around intellectual property raised the possibility of an innovative response from the postgraduate students. The students had a range of ways of responding to copyright infringements and made a number of recommendations on the academics' materials:

So if something isn't vital, or serving some kind of purpose, just take it out. It saves much time, than having to re-look for ... clipart.... I don't know why they put it in, they thought it would be a nice image to jazz up the book, so they had it everywhere. ... The other thing I always tell them is if you're using a particular kind of image for a section just make it all uniform, don't have a photograph here and then the next one you have a vector image here, then you have this and then you have that. Rather just make it all the same. That's the other rule I have, "embrace the power of Flickr," look on Flickr for images under Creative Commons licenses. Stop trying to search for stuff and claim it's in the public domain. (Student 4) 


\section{A growing sense of agency}

A more profound finding from this small study was the way in which the postgraduate students revealed a growing sense of agency as they moved from merely removing unnecessary local details about assignment dates or tests from the materials and removing copyrighted materials through questioning the suitability of the materials and making decisions about alternative images and/or text, to making decisions about leaving out entire sections of the academics' materials, and providing the academics with new rules about OER development.

Engeström's interpretive layer (2011) takes into account the rule-bound activities of the postgraduate students as they removed "UCT specific content" (Student 6). Engeström's contradictory layer (2011) helps locate the postgraduate students' questioning of the relevance or suitability of the materials, as illustrated in responses such as: "I don't know why they put it in, they thought it would be a nice image to jazz up the book, so they had it everywhere" (Student 4) and "Sometimes they would have a diagram just for its own sake, and afterwards you would think how does this actually relate?" (Student 2). Engeström's agentive layer explains how postgraduate students started to transform the activity by creating new ways to respond to the challenges they faced in co-authoring OER (2011). These transformative actions are illustrated in the students' decisions to leave out materials altogether (e.g., "Many times in the slides, especially the slides that we didn't include, people felt that they had to fill every available bit of space" [Student 2]) or create new rules for OER development (e.g., "That's the other rule I have, 'embrace the power of Flickr,' look on Flickr for images under Creative Commons licenses. Stop trying to search for stuff and claim it's in the public domain" [Student 4]).

\section{Discussion}

Using Engeström's concept of two interacting activity systems (2001), the value that the postgraduate students bring to the OER adaption process becomes clearer as the contradictions present in the traditional process of creating teaching materials for classes are mapped against the innovative process of sharing teaching materials to optimize social inclusion. The modeling process can help identify the role that the postgraduate students can play in assisting academics to rework or co-author existing teaching materials as OER (Figure 3). The triangle on the left represents the activity system of materials development by academics and the one on the right

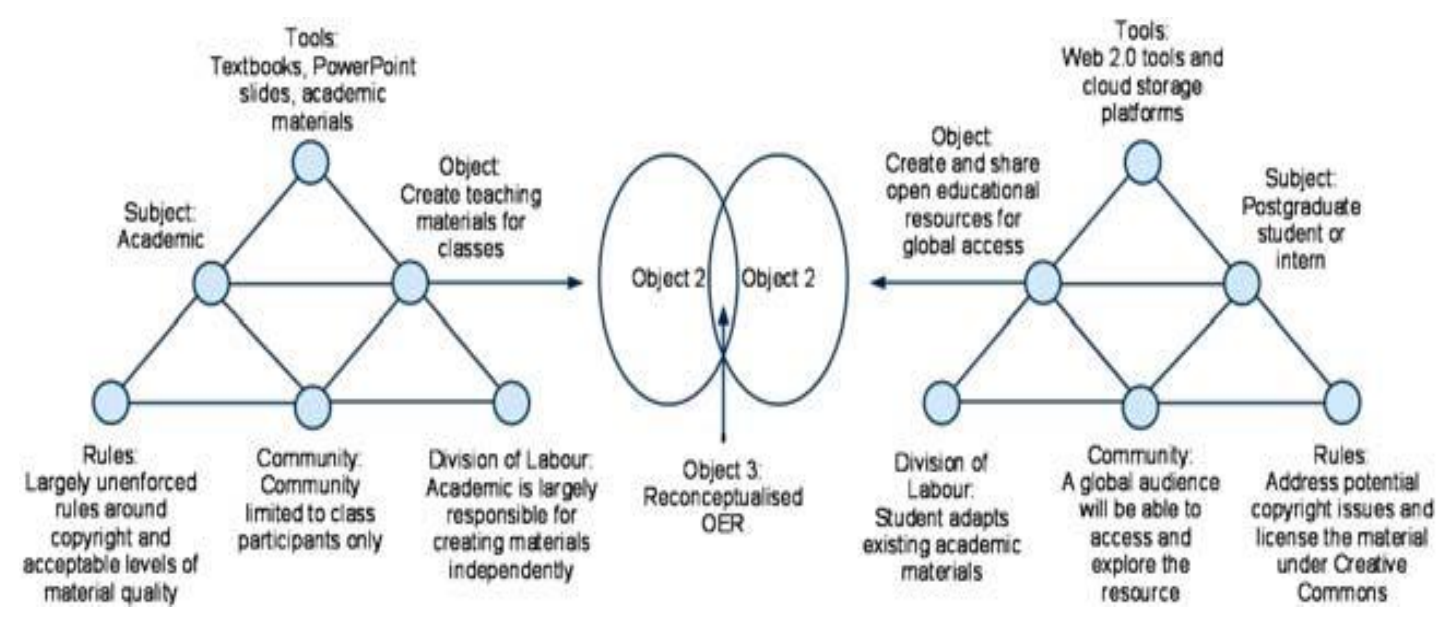

Figure 3. Interacting activity systems (Engeström, 2001, p. 136). 
represents the activity system of the adaptation of these materials by the postgraduate students.

The subject in the triangle on the left is the academic who uses a limited number of mediating artifacts, such as extracts from textbooks and presentation software, to create teaching materials for his/her community, the UCT students. The materials are most likely to be hosted on a private computer, on the institutional LMS, or occasionally on an open Web site. The academic usually undertakes the development of the materials him- or herself, so the division of labor rests solely on the shoulders of the academic. The academic adheres in part to intellectual property rules, but is likely to infringe these with respect to images from textbooks or the Web. The academic is unlikely to add any descriptive metadata to his/her teaching materials.

The subject in the triangle on the right reflects the postgraduate students who use a far wider range of mediating artifacts than the academics to adapt or even create teaching materials. These are likely to include PowerPoint slides hosted on SlideShare, photographs hosted on Flickr, videos on YouTube, HTML to design a Web page, and materials in a range of formats depending on the users' needs. The materials are hosted on the most suitable platform and linked to the UCT OpenContent directory. The division of responsibility for the preparation of the OER is shared by the students who adapt the original materials prepared by the academic.

The postgraduate students are likely to remove what they deem to be unnecessary information or images, redraw copyrighted images they consider to be essential, or replace copyrighted images with Creative Commons licenses. They will add metadata and usually an image of the OER to make it easily discoverable on UCT OpenContent or any of the other OER aggregators that harvest materials from OER repositories and directories.

The transformed object (3) is the OER reconceptualized for the public, which may be an even better teaching resource than the original. The outcome of adapting teaching materials to be shared as OER is that of a more discoverable and accessible resource available online to anyone with an Internet connection. In terms of being able to make OER socially inclusive, postgraduate students can assist academics in reconceptualizing the purpose of teaching materials for a public audience.

Given the fact that they are students themselves, they are able to note where material is not relevant or where information (including text, images, audio) needs to be added, removed, or placed in a specific sequence to make the materials comprehensible as stand-alone resources. They may also be able to help with translations of the materials if they have the necessary capability. Given their knowledge of open platforms available on cloud-based services or institutional repositories, postgraduate students can be helpful in uploading, updating, or deleting OER materials, and ensuring that they have a suitable license, descriptive metadata, and captivating resource images. Postgraduate students are also quite familiar with various Web-based tools and a range of media formats and can therefore assist in making OER accessible to a public audience. Most importantly, postgraduate students may be helpful in advising on appropriate Creative Commons licensing, clearing copyrighted texts and images, and locating alternative open images.

Perhaps more important is the postgraduate students' growing sense of agency displayed by the increasing gradations of action in which the students became involved as they moved through what Engeström (2011) referred to as an interpretive layer, where agency is limited to following the basic rules, in this case of 


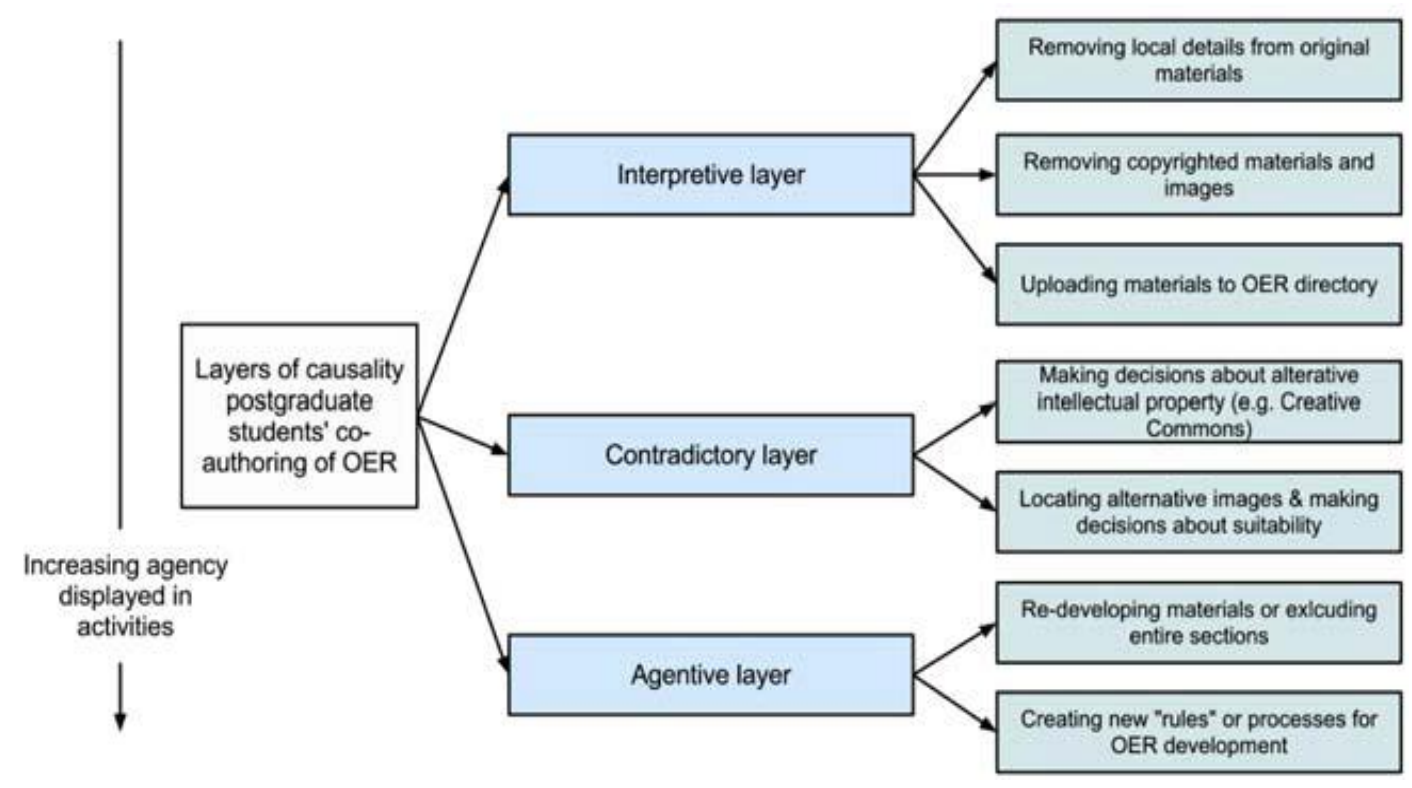

Figure 4. Increasing agency displayed by postgraduate students co-authoring OER (adapted from Engeström, 2011, p. 610).

copyright and relevance of the materials they were reworking as OER, to the contradictory layer, where they questioned the necessity or suitability of materials, to the agentive layer, where they actively made decisions about what they saw as unnecessary and what new OER processes they envisaged. This growing agency can be explained by Engeström's three layers of causality (2011) (Figure 4).

\section{Conclusion and recommendations}

Through the lens of activity theory (Engeström, 2001), and particularly his concept of contradictions and layers of causality this article surfaces some of the disruptive activities and potential transformations that have emerged in the process of postgraduate students or interns reworking the content in collaboration with the academics for both the social inclusion of others to access the material and the social inclusion of students' voices in the development of academic teaching materials to be shared as OER.

Given the fact that postgraduate students have a wider range of experience using new mediating tools to draw upon, more in-depth knowledge of alternative copyright rules such as Creative Commons, and understand how to compose metadata and link materials to a range of hosting platforms and OER directories, it would seem a pity not to harness this potential to improve teaching materials for use by local students and the public. The postgraduate students have also provided evidence of their commitment to sharing teaching materials with those usually excluded from the traditional university and their engagement with the OER development process has also revealed a growing sense of their agency in supporting the OER process.

\section{Acknowledgements}

The authors would like to thank the Centre for Higher Education Development at the University of Cape Town for a grant to undertake this research and to the senior students supported by the UCT OER Project and the African Health OER Project for their participation in this study. 


\section{Notes on contributors}

Cheryl Hodgkinson-Williams is an associate professor in the Centre for Educational Technology at the University of Cape Town (UCT), South Africa, where she has been since 2007. Prior to joining UCT, she was an associate professor of ICTs in education at Rhodes University in Grahamstown, South Africa.

Michael Paskevicius recently completed his master's degree specializing in educational technologies at the University of Cape Town. He currently works in the Centre for Educational Technology as a learning technologist supporting and researching emerging technologies in higher education.

\section{References}

Altbach, P. G., Reisberg, L., \& Rumbley, L. E. (2009). Trends in global higher education: Tracking an academic revolution (Report prepared for the UNESCO 2009 World Conference on Higher Education). Paris: UNESCO. Retrieved from http://unesdoc.unesco.org/ images/0018/001832/183219e.pdf

Canby, B., Hutchful, D., Kleymeer, P., \& Ngo, B. (2007). A financial analysis of steady-state operations of UMMS global access. Ann Arbor: University of Michigan. Retrieved from http://open.umich.edu/sites/default/files/images/bit648-f07-umms_global_access-financial_ analysis-12.2007.pdf

Commonwealth of Learning. (2011). Guidelines for open educational resources (OER) in higher education. Vancouver: Author. Retrieved from http://www.col.org/PublicationDocuments/Guidelines_OER_HE.pdf

Conole, G. (2011, February). Social exclusion or inclusion in a Web 2.0 world. Keynote presented at the DEHub Summit, Education 2011 to 2021: Global challenges and perspectives of blended and distance learning, Sydney. Retrieved from http://cloudworks.ac.uk/ cloud/view/5040

Conole, G., McAndrew, P., \& Dimitriadis, Y. (2010). The role of CSCL pedagogical patterns as mediating artefacts for repurposing open educational resources. In F. Pozzi \& D. Persico (Eds.), Techniques for fostering collaboration in online learning communities: Theoretical and practical perspectives (pp. 206-223). Hershey, PA: IGI Globaldoi:10.4018/978-1-61692-898-8.ch012

Coughlan, T., \& Perryman, L.-A. (2011). Something for everyone? The different approaches of academic disciplines to open educational resources and the effect on widening participation. Journal of Open, Flexible and Distance Learning, 15(2), 11-27. Retrieved from http://journals.akoaotearoa.ac.nz/index.php/JOFDL

dos Santos, A. I. (2008). The discourses of OERs: How flat is this world? Journal of Interactive Media in Education, 11, 1-10. Retrieved from http://jime.open.ac.uk/

Ehlers, U.-D. (2011). Extending the territory: From open educational resources to open educational practices. Journal of Open, Flexible and Distance Learning, 15(2), 1-10. Retrieved from http://journals.akoaotearoa.ac.nz/index.php/JOFDL

Engeström, Y. (2000). Activity theory as a framework for analyzing and redesigning work. Ergonomics, 43, 960-974. doi:10.1080/001401300409143

Engeström, Y. (2001). Expansive learning at work: Toward an activity theoretical reconceptualization. Journal of Education and Work, 14, 133-156. doi:10.1080/713677004

Engeström, Y. (2011). From design experiments to formative interventions. Theory \& Psychology, 21, 598-628. doi:10.1177/0959354311419252

Geser, G. (Ed.). (2007). Open educational practices and resources: OLCOS Roadmap 2012. Salzburg: Open eLearning Content Observatory Services. Retrieved from http://www. olcos.org/cms/upload/docs/olcos_roadmap.pdf

Gidley, J. M., Hampson, G. P., Wheeler, L., \& Bereded-Samuel, E. (2010). From access to success: An integrated approach to education informed by social inclusion theory and practice. Higher Education Policy, 23, 123-147. doi:10.1057/hep. 2009.24

Gourley, B., \& Lane, A. (2009). Re-invigorating openness at The Open University: The role of open educational resources. Open Learning: The Journal of Open, Distance and eLearning, 24(1), 57-65. doi:10.1080/02680510802627845 
Harris, R., \& Higgison, C. (2003). Reuse of resources within communities of practice. In A. Littlejohn (Ed.), Reusing online resources: A sustainable approach to e-learning (pp. 234-247). London: Kogan Page.

Hodgkinson-Williams, C. A., \& Donnelly, S. (2010). Sustaining OER at the University of Cape Town: Free, but not cheap. In OpenEd 2010, Proceedings of the Seventh Open Education Conference (pp. 215-226). Barcelona: Universitat Oberta de Catalunya, Open Universiteit Nederland, \& Brigham Young University. Retrieved from http://hdl.handle. net/10609/4843

Honkaranta, A., \& Tyrväinen, P. (2005). May reusable text-based learning objects exist? Using genre theory for analysing reusability of learning objects. In Proceedings of the 1st WSEAS/IASME International Conference on Educational Technologies (pp. 39-45). Retrieved from http://www.wseas.us/e-library/conferences/2005tenerife/papers/502-600. pdf

Kleymeer, P., Kleinman, M., \& Hanss, T. (2010). Reaching the heart of the university: Libraries and the future of OER. In OpenEd 2010, Proceedings of the Seventh Open Education Conference (pp. 241-250). Barcelona: Universitat Oberta de Catalunya, Open Universiteit Nederland, \& Brigham Young University. Retrieved from http://hdl.handle. net/10609/4866

Lane, A., \& van Dorp, K. J. (2011). Open educational resources and widening participation in higher education: Innovations and lessons from open universities. In L. Gómez Chova, D. Martí Belenguer, \& A. López Martínez (Eds.), Proceedings of EDULEARN11, 3rd International Conference on Education and New Learning Technologies (pp. 13531363). Valencia: International Association of Technology, Education and Development. Retrieved from http://oro.open.ac.uk/29201/1/OPEN_EDUCATIONAL_RESOURCES_ AND_WIDENING_PARTICIPATION_andy.pdf

LeCompte, M. (2000). Analyzing qualitative data. Theory into Practice, 39, 146-154. doi:10.1207/s15430421tip3903_5

Lee, M. J. W., \& McLoughlin, C. (2007). Teaching and learning in the Web 2.0 era: Empowering students through learner-generated content. International Journal of Instructional Technology and Distance Learning, 4(10), 21-34. Retrieved from http://www.itdl. org/

Little, S., Mikroyannidis, A., Okada, A., \& Scott, P. J. (2011). Formal metadata and shared experiences for discovering tools to adapt open educational resources. In SITIS 2011, 7th International Conference on Signal Image Technology \& Internet Based Systems (pp. 147-153). Washington, DC: IEEE Computer Society.

Littlejohn, A., Jung, I., \& Broumley, L. (2003). A comparison of issues in reuse of resources in schools and colleges. In A. Littlejohn (Ed.), Reusing online resources: A sustainable approach to e-learning (pp. 212-220). London: Kogan Page.

Maxwell, J. (2008). Designing a qualitative study. In L. Bickman \& D. J. Rog (Eds.), The Sage handbook of applied social research methods (pp. 214-252). London: Sage.

McAndrew, P. (2006). Motivations for OpenLearn: The Open University's open content initiative. Milton Keynes: Open University. Retrieved from http://www.oecd.org/dataoecd/4/ 56/38149250.pdf

Ngugi, C. (2011). OER in Africa's higher education institutions. Distance Education, 32, 277-287. doi:10.1080/01587919.2011.584853

Paskevicius, M. (2011). Student perceptions of the reuse of digital educational materials: A case study of the social outreach group SHAWCO (Unpublished MPhil dissertation). University of Cape Town, Cape Town, South Africa. Retrieved from http://srvrhldig001. uct.ac.za/R/?func=dbin-jump-full\&object_id=11605

Philip, R., \& Cameron, L. (2008). Sharing and reusing learning designs: Contextualising enablers and barriers. In J. Luca \& E. Weippl (Eds.), Proceedings of World Conference on Educational Multimedia, Hypermedia and Telecommunications (pp. 453-462). Chesapeake, VA: AACE.

Sapire, I., \& Reed, Y. (2011). Collaborative design and use of open educational resources: A case study of a mathematics teacher education project in South Africa. Distance Education, 32, 195-211. doi:10.1080/01587919.2011.584847

Shuttleworth Foundation. (n.d.). Cape Town open education declaration: View signatures. Retrieved from http://www.shuttleworthfoundation.org/read-the-declaration 
Stake, R. E. (1995). The art of case study. Thousand Oaks, CA: Sage.

University of Cape Town. (2009). The strategic plan for the University of Cape Town 2010 2014. Cape Town: Author. Retrieved from http://www.uct.ac.za/downloads/uct.ac.za/ about/goals/uct_strategic\%20goals.pdf

University of Michigan. (2011). Open.Michigan Wiki [Wiki]. Retrieved from https://open. umich.edu/wiki/DScribe

Wheeler, S. (2010, October). Open for use? Challenge of user generated content and its impact on open educational resources. Keynote presentation to the EDEN Research Workshop, Budapest. Retrieved from http://www.slideshare.net/timbuckteeth/eden-oerworkshop-keynote-2010-upload-version

Wolfenden, F. (2008, May). The TESSA OER experience: Building sustainable models of production and user implementation. Journal of Interactive Media in Education.

Retrieved from http://jime.open.ac.uk/ 